\title{
State of the art in the treatment of lung cancer
}

\author{
B Jeremic, $\mathrm{MD}, \mathrm{PhD}$ \\ Institute of Lung diseases, Sremska Kamenica and BioIRC Centre for Biomedical Research, Kragujevac, Serbia
}

Corresponding author: B Jeremic (nebareje@gmail.com)

\begin{abstract}
Lung cancer is the major cancer killer in both sexes. Despite many biological and technological achievements, it is still mostly an incurable disease, and survival figures are only modestly improved in the past few decades. Optimisation of treatment is usually sought through clinical studies, but unfortunately only a few per cent of lung cancer patients enter these world-wide. So it is in spite of the fact that we have witnessed the introduction of robotic surgery, computerised radiation therapy and targeted agents in daily clinical practice. More emphasis on clinical research is therefore needed to improve our capability to successfully treat lung cancer.
\end{abstract}

S Afr Resp J 2015;21(3):59-65. DOI:10.7196/10.2015.v21i3.59

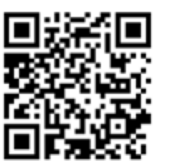

Lung cancer continues to be the major cancer killer in both sexes world-wide. ${ }^{[1]}$ Approximately 1.6 million new cases of lung cancer are diagnosed each year. ${ }^{[2]}$ While the number of cases continues to increase in many places around the world, the overall cure rate from lung cancer is modest (approximately 17\%) because the majority of patients present with advanced stage at diagnosis. This is irrespective of refinements in histological aspects, better diagnostic and staging tools, including the massive influence of positron emission tomography (PET) scanning, as well as a sharp shift towards molecular oncology already found its way to clinic. The most recent update of staging by the International Association for the Study of Lung Cancer (IASLC) provided an important addition to the issue. ${ }^{[3]}$ Treatment paradigm may therefore be seen as even more important nowadays since it ultimately should match pre-treatment advances. Although there are many treatment modalities employed in lung cancer, each of which continues to develop, we will concentrate on the three most effective ones, namely surgery, radiation therapy (RT) and drug therapy, the latter one including both chemotherapy (CHT) and targeted therapy. This review article aims to summarise current aspects of treatment in lung cancer with the three treatment modalities being used in both non-small-cell lung cancer (NSCLC) and small-cell lung cancer (SCLC).

\section{NSCLC}

\section{Early stage}

In patients with early-stage (I-II) NSCLC, surgical resection remains the cornerstone of treatment. Unfortunately, less than $30 \%$ of patients have their disease resectable at the time of presentation, and 50\% of these have significant comorbidities. While being technically operable, they are considered medically inoperable. Furthermore, approximately $70 \%$ of the patients with early-stage resected disease develop recurrence at distant sites. Therefore, additional systemic therapy is needed to eradicate micrometastatic disease. In this setting, platinum-based CHT has emerged as an effective adjuvant systemic therapy after resection. The International Adjuvant Lung Trial (IALT), with more than 1700 patients with stages I-III NSCLC, demonstrated a significant but modest improvement in 5-year survival rate of $4 \%$ when adding cisplatin-based doublets after surgery (versus observation). ${ }^{[4]}$ Similarly, cisplatin-vinorelbine v. observation was compared in patients with stages IB and II NSCLC in the National Cancer Institute of Canada (NCIC) trial. ${ }^{[5]}$ An overall $15 \%$ improvement in 5-year survival in the adjuvant $\mathrm{CHT}$ group was observed. Finally, a meta-analysis of trials with adjuvant cisplatinbased CHT demonstrated a 5\% improvement in overall survival (OS $)^{[6]}$ ultimately leading to a shift of treatment paradigm. However, it must be clearly stated that the role of adjuvant CHT has been limited to stage II and III resected NSCLC due to a preferential benefit observed in these subgroups. However, controversy remains including the data to support its use in those with tumours $\geq 4 \mathrm{~cm}$ in size. ${ }^{[6]}$ For patients with stage IA disease, adjuvant CHT is not usually recommended. ${ }^{[7]}$

Cisplatin-based CHT is the 'standard of care' in the adjuvant setting. However, a controversy exists on whether carboplatin can be substituted for cisplatin in the adjuvant setting. A trial of carboplatin/ paclitaxel combination in patients with stage $1 \mathrm{~B}$ disease failed to show a survival benefit, despite improvement in disease-free survival. ${ }^{[7]}$ The optimal number of cycles of adjuvant CHT has also not been addressed in randomised studies. Currently, 3 - 4 cycles of cisplatinbased CHT are administered in routine practice settings.

Approximately two-thirds of all resected patients are able to receive adjuvant $\mathrm{CHT}$ as others have comorbidities of varying degree and/or postoperative complications. Neo-adjuvant (induction) $\mathrm{CHT}$ has also been investigated to improve the delivery and compliance of CHT. A phase III study demonstrated an improvement in overall survival with neo-adjuvant $\mathrm{CHT}$ followed by surgery versus surgery alone. ${ }^{[8]}$ However, the difference was not significant and the trial was closed early because adjuvant $\mathrm{CHT}$ became the new 'standard of care'. Similar data have also been reported from another trial that evaluated preoperative therapy. ${ }^{[9]} \mathrm{Neo}$-adjuvant $\mathrm{CHT}$ prior to surgery versus surgery alone versus surgery followed by adjuvant $\mathrm{CHT}$ was compared in the Spanish Study. The delivery of CHT was found to be superior in the pre-operative setting (90\% v. 66\%). ${ }^{[10]} \mathrm{Neo}$-adjuvant $\mathrm{CHT}$ in this trial was associated with a non-significant trend towards longer diseasefree survival compared with surgery alone. The power of this study was limited and there was a high proportion of stage I patients who supposedly do not benefit from systemic therapy. Neo-adjuvant CHT is an efficacious and safe approach for patients with early-stage NSCLC 
but the 'standard of care' for patients with $\mathrm{R}_{0}$ resection is adjuvant $\mathrm{CHT}$.

In the adjuvant setting, epidermal growth factor receptor (EGFR) inhibitors have also been investigated for patients with resected early-stage NSCLC. Though gefitinib as adjuvant therapy failed to demonstrate a benefit in this group, this was not conclusive as the study was stopped early. ${ }^{[1]}$ Erlotinib has been evaluated in a randomised trial (RADIANT) in the adjuvant setting. The trial has completed accrual and the results are eagerly awaited.

While surgery remains the gold standard in operable early NSCLC, there are patients who either cannot tolerate lobectomy or are considered borderline cases. Beside more limited surgery (e.g. segmentectomy or wedge resection) occasionally used in such cases, ${ }^{[12-15]}$ standard fraction, hyper- or hypo-fractionated thoracic radiation therapy (TRT) and even TRT-CHT was used with modest success in this largely unfavourable patient population. ${ }^{[16,17]}$ Importantly, stereotactic body radiotherapy (SBRT) has been used with excellent local control and overall survival largely surpassing results achievable with conventional RT. ${ }^{[18,19]}$ Recent comparisons, though not done in a prospective randomised fashion, indicated similar outcomes with surgery versus SBRT. ${ }^{[20,21]}$ Although both limited surgery and SBRT produce excellent results given exclusively, requests for more formal comparison of two treatment approaches led to two prospective randomised trials that are currently underway.

\section{Locally advanced disease}

Approximately one-third of all patients with NSCLC present with a locally advanced, mostly stage III disease. It has been the major battleground for investigating various treatment options. Surgery (e.g. in very selected T4N0), TRT (altered fractionation regimens with curative intention in stage III or palliative hypofractionated regimens in mostly stage IIIB patients) and various CHT agents (again, mostly in stage IIIB) can all be used alone in this disease. However, this is not so frequent practice nowadays in the majority of patients who can tolerate a more intensive (combined) treatment approach owing to the best success rate obtained with a bimodality (TRT-CHT) approach.

In the domain of RT alone, standard fraction and altered fractionation regimens (e.g. hyperfractionation, hypofractionation) have been used to improve local control, showing promising results such as continuous hyperfractionated accelerated radiation therapy (CHART). ${ }^{[22]}$ This treatment design (three daily fractions separated with a 6-hour interval) was unfortunately extremely complicated for daily clinical practice, which has prevented it from widespread use.

TRT and platinum-based CHT have been increasingly practised around the world in the last three decades. A number of possible combinations have arisen. Neo-adjuvant $\mathrm{CHT}$ followed by radical TRT, ${ }^{[23,24]}$ 'sandwich' CHT and TRT ${ }^{[25]}$ as well as concurrent TRT$\mathrm{CHT}^{[26-28]}$ have all gained widespread use. The latter of the three approaches denotes the administration of both modalities at the same time, meaning that CHT is given during the course of radical TRT. Its main aim is to address the issue of locoregional and distant disease at the same time, from the beginning of the treatment as intensively as possible. Several clinical trials directly compared the two approaches with somewhat conflicting results. Therefore, meta-analyses were undertaken to solve the issue of the timing of administration of RT and $\mathrm{CHT}$ in this setting.

In the analysis of O'Rourke et al ${ }^{[29]}$ with nineteen randomised studies
TRT and concurrent CHT significantly reduced overall risk of death (hazard ratio (HR) 0.71, 1607 participants) and overall progressionfree survival (PFS) at any site (HR 0.69, 1145 participants). Liang et al. ${ }^{[30]}$ performed a systematic review of 11 trials (2 043 patients; 1019 concurrent, 1024 neo-adjuvant) to confirm that TRT and concurrent CHT offered a statistically significant increase in median survival time $($ MST) $(16.3$ v. 13.9 months; pooled median ratio $=1.17)$, response rate $(64.0 \%$ v. $56.3 \%$; odds ratio $=1.38)$, and tumour-relapse control (odds ratio $=0.82$ ). Finally, Auperin et al. ${ }^{[31]}$ used updated individual patient data of six trials (1 205 patients, $92 \%$ of all randomly assigned patients) to document a significant benefit of TRT and concurrent CHT on overall survival (pooled HR, 0.84; $p=0.004$ ), with an absolute benefit of $5.7 \%$ (from $18.1 \%$ to $23.8 \%$ ) at 3 years and $4.5 \%$ at 5 years. For progression-free survival, the pooled HR was $0.90(p=0.07)$. TRT and concurrent CHT decreased locoregional progression (pooled HR, $0.77 ; p=0.01$ ); its effect was not different from that of induction treatment on distant progression (pooled HR, 1.04; $p=0.69$ ). With these meta-analyses the story of superiority of TRT and concurrent CHT over the neo-adjuvant CHT followed by radical TRT seems to finally be over, while further studies should attempt to optimise concurrent approach.

It should not be forgotten that there is continued discussion regarding the role of surgery for these patients. Four randomised studies noted no overall survival differences comparing operative v. non-operative approaches in patients with (mostly) stage IIIA lung cancer. ${ }^{[32-35]}$ An unplanned subset analysis of the most contemporary of these trials, Intergroup 0139, ${ }^{[35]}$ did suggest a difference on survival based on surgical approach. Mortality rates with pneumonectomy were excessively high, while lobectomy patients appeared to have improved outcomes. It remains nonetheless appropriate to conclude that the sum of the evidence to date supports the proposition that a non-surgical approach constitutes the 'standard' for stage III patients.

Contrary to curative approaches discussed above, about two-thirds of the NSCLC population is diagnosed with incurable disease and should be treated with a palliative intent. Most of these patients will have symptoms from an intrathoracic tumour at diagnosis or have the propensity to develop symptoms in the near future. In this setting, any intervention should have the goal of effective palliation avoiding unacceptable toxicity. Various TRT fractionation schemes are in use for palliative treatment, ranging from as low as single fraction of 8 - 10 Gy to as high as fractionated 50 - 60 Gy. Until the first study from the Medical Research Council (MRC) UK was published in $1991,{ }^{[36]}$ a typical course was $30 \mathrm{~Gy}$ in 10 fractions. Since then, several randomised phase III trials ${ }^{[37-44]}$ comparing a strict hypofractionated schedule versus a normo-fractionated regimen have been published, with $>2500$ patients being treated. All trials have either a single ( 8 or $10 \mathrm{~Gy}$ ) or two large fractions ( $17 \mathrm{~Gy} / 2$ or $16 \mathrm{~Gy} / 2$ ) as the shortcourse experimental arm. The comparative fractionated schedules ranged from 20 to $50 \mathrm{~Gy}$. The trials included patients up to World Health Organization performance status (WHO PS) 3 with a huge shift towards stage III patients. One trial (MRC II) ${ }^{[37]}$ included only patients with WHO PS 2 - 4 comparing a single fraction versus $17 \mathrm{~Gy} / 2$ fractions. In two trials, ${ }^{[42,43]}$ the effect on symptoms was in favour of the higher dose, otherwise the effect on disease-related symptoms was equal. In three trials, ${ }^{[38,40,43]}$ the survival was in favour of the high-dose arm: $39 \mathrm{~Gy} / 13$ fractions, $30 \mathrm{~Gy} / 10$ fractions and $30 \mathrm{~Gy} / 10$ fractions, 
respectively. One trial ${ }^{[44]}$ reported a survival benefit for the low-dose arm: $16 \mathrm{~Gy} / 2$ fractions v. $20 \mathrm{~Gy} / 5$ fractions. In another trial, ${ }^{[41]} 17 \mathrm{~Gy} / 2$ fractions ( $n=143)$ was compared with two high-dose arms: $42 \mathrm{~Gy} / 15$ fractions $(n=140)$ and $50 \mathrm{~Gy} / 25$ fractions $(n=124)$, with no difference in median survival found.

Five randomised phase III studies ${ }^{[45-49]}$ have compared different normo- to high-dose regimens, including more than 1000 patients. Nearly all had stage III localised disease with a reasonably good performance status (WHO PS 0 - 2). One study reported better palliation in the high-dose arm. ${ }^{[46]}$ Four studies provided data on survival, being equal in three and better for the high-dose arms in one. ${ }^{[48]}$ The latter study ${ }^{[48]}$ is particularly interesting since one arm in this three-armed trial was a 'wait and see' arm; 40 Gy10 (split) v. 50 Gy/25 v. 'wait and see. The survival in this 'wait and see' arm was inferior compared with the two actively treated arms.

While the effect on symptoms and palliative effect may be similar regardless of dose and fractionation, the trend of more rapid relief of symptoms in favour of hypofractionation is observed with no major difference in median survival. To investigate the issue of whether some patients with localised stage III disease may benefit from a protracted high-dose TRT, an MRC study ${ }^{[38]}$ was undertaken focusing only on stage III disease with good performance status. It compared $17 \mathrm{~Gy} / 2$ fractions (arm 1) with $39 \mathrm{~Gy} / 13$ fractions ( $\operatorname{arm} 2$ ). The median survival increased from 7 to 9 months in arm 2 ( $p>0.05)$, with a 1- and 2-year survival of $31 \%$ and $9 \%$ v. $36 \%$ and $12 \%$ in the arm 1 and arm 2 , respectively. Another study ${ }^{[41]}$ compared a strict low-dose with high-dose schedules and found a trend in better survival in the high-dose arms. Further analysis of the same study (restricted to stage III patients) ${ }^{[50]}$ disclosed a 3- and 5-year survival in the three arms (17 Gy/2, 42 Gy/15, 50 Gy/25) of $1 \%, 8 \%$ and $6 \%$, v. $0 \%, 4 \%$ and $3 \%$, respectively. General observations from all of these studies can be extrapolated to patients with stage IV, which can also safely be treated with a hypofractionated schedule. Acute toxicity with dysphagia is mild, temporary and manageable. Late toxicity is rare, sporadic and usually not severe.

Although there was no strong evidence that higher dose gives a better outcome concerning symptom relief and survival, and that a hypofractionated regimen is an option for most patients, patients with stage III disease with a reasonable performance status and less weight loss could be treated with a protracted fractionated regimen 30 - 45 Gy. Stage IV patients can be treated safely with a hypofractionated regimen in almost all cases. Not to be forgotten, palliative TRT can unexpectedly generate some long-term survivors. ${ }^{[50,51]}$ Approximately $1-3 \%$ of patients with localised disease have been found with 5 -year survival after palliative high-dose TRT. This can perhaps be explained by the unpredictably high radiosensitivity of some lung tumours.

In the last two decades the effect of CHT in advanced NSCLC has been recognised. ${ }^{[52]}$ Treatment with CHT should be restricted to patients with a reasonably good performance status (WHO PS $\leq 2$ ). Most patients with advanced NSCLC will therefore be offered CHT as first-line treatment. However, CHT can generate toxicity and not all patients are considered fit. For these patients, primary palliative TRT is a good option. Furthermore, it can be offered to patients progressing during or after CHT with less toxicity.

Palliative TRT aims to treat symptoms from intrathoracic tumours. In otherwise symptom-free patients, however, immediate treatment is likely to give unnecessary side-effects like dysphagia and may not prevent development of later symptoms. ${ }^{[3,54]} \mathrm{A}$ 'wait and see' procedure is therefore advocated until the patient becomes symptomatic.

\section{Advanced/metastatic disease}

Systemic therapy remains the mainstay for treatment of advancedstage NSCLC. Combination CHT with a platinum-based regimen (cisplatin or carboplatin) has emerged as standard therapy for patients with advanced-stage disease. ${ }^{[55]}$ Improvements in overall survival and quality of life have been demonstrated with platinum-based regimens over best supportive care alone in randomised clinical trials. ${ }^{[56]}$ In general, carboplatin-based regimens have a favourable tolerability over cisplatin-based regimens. ${ }^{[57,58]}$ Despite the marginally higher response rate with cisplatin-based regimens, and considering the palliative intent of therapy, carboplatin-based regimens have found wide applicability in routine care. Recent improvements in anti-emetic therapy have made cisplatin-based regimens more tolerable.

A number of randomised clinical trials have established the superiority of platinum-doublets over single-agent therapy. ${ }^{[59-61]}$ The 'third-generation' cytotoxic agents (paclitaxel, docetaxel, gemcitabine, vinorelbine, irinotecan and pemetrexed) have all demonstrated efficacy when given in combination with a platinum compound in patients with advanced NSCLC. ${ }^{[57,59,62-65]}$ The use of triplets has generally resulted in higher toxicity without clear evidence of improvement in efficacy and has therefore largely been abandoned ${ }^{[66]}$ With the currently available platinum-based two-drug regimens, the median survival and 1-year survival rate are $8-11$ months and $30-40 \%$ in patients with a good PS. ${ }^{[67]}$

\section{Histology-based treatment of advanced NSCLC}

Choice of systemic therapy based on the histological subdivision of NSCLC is a new paradigm. It was shown that the cisplatinpemetrexed combination was associated with increased efficacy in non-squamous NSCLC. ${ }^{[68]}$ In patients with adenocarcinoma, the median survival with the cisplatin-pemetrexed regimen was 12.6 compared with 10.9 months with cisplatin-gemcitabine $(p<0.05)$. Improved efficacy of pemetrexed in adenocarcinoma may in fact be due to low levels of expression of thymidylate synthase (TS), a known target for pemetrexed $(68,69)$ in adenocarcinoma compared with squamous or small-cell carcinoma. ${ }^{[70]}$ In addition, this regimen was also associated with a favourable tolerability profile. These results led to the approval of the cisplatin-pemetrexed regimen for patients with only non-squamous NSCLC.

\section{Maintenance therapy}

Until recently, 4 - 6 cycles of combination CHT formed the 'standard of care' for patients with advanced NSCLC. ${ }^{[71,72]}$ Extension of the same treatment failed to demonstrate any evidence of benefit. Recent trials of maintenance therapy in stable/responding patients to front-line regimen have shifted the treatment paradigm in favour of this approach. Pemetrexed and erlotinib, administered as single agents, are widely used for maintenance therapy based on the results of randomised trials, ${ }^{[73,74]}$ including tolerability and the lack of a significant cumulative toxicity. The benefit is more provocative with erlotinib in those with activating mutations in the EGFR TK domain although it is modest at best in the overall populations. The metaanalysis of maintenance therapy studies demonstrates a significant 
improvement in progression-free survival and a modest improvement in overall survival. ${ }^{[75]}$

Continued controversy among lung cancer care providers exists regarding the optimal patient type for the maintenance therapy and the choice of agent (continuation of the same agent v. switch to a new agent). For now 'switch maintenance' has been established until new data become available. Patients with poor or declining PS should not be offered maintenance therapy. ${ }^{[76]}$

\section{EGFR tyrosine kinase inhibitors (TKIs)}

EGFR pathway inhibitors gefitinib and erlotinib were evaluated in patients with refractory NSCLC, with a single agent activity observed in approximately $10-20 \%$ of the patients. ${ }^{[77-79]}$ The NCIC-BR2 1 study documented significant improvement in overall survival and progression-free survival with erlotinib in patients with recurrent (second-line) advanced NSCLC. ${ }^{[80]}$ However, gefitinib failed to show a difference in overall survival when compared with a placebo ${ }^{[81]}$ but the subsets of never-smokers/Asian ethnicity patients demonstrated a benefit. Clinical characteristics for response for EGFR TKIs in the early trials included female sex adenocarcinoma histology, neversmokers and those with Asian ethnicity, ${ }^{[82]}$ likely due to an incidence of EGFR activity mutations in the tyrosine kinase domain of the receptor responsible for the selective activity with EGFR TKIs being much higher ( 40\%) in those with Asian ethnicity. Recent landmark Asian phase III study confirmed the role of EGFR mutation as the main predictor of outcome with EGFR tyrosine kinase inhibitors. ${ }^{[83]}$ It was also shown that administration of gefitinib in patients with wild-type EGFR was not warranted and CHT remains the preferred treatment. Another Asian study ${ }^{[84]}$ confirmed these observations. Adding CHT and EGFR TKIs in the front-line setting in patients with tumours harbouring the EGFR mutation has no benefit. ${ }^{[85,86]}$ Furthermore, a recent trial in never- or light-smokers investigated erlotinib alone or in combination with carboplatin and paclitaxel ${ }^{[87]}$ and found no difference between the two groups even in patients with EGFR mutation, thus excluding a role for combination of EGFR TKIs with CHT.

Cetuximab, a chimeric monoclonal antibody against the EGFR, has minimal activity when given as monotherapy for patients with advanced-stage NSCLC. ${ }^{[88]}$ However, when given in combination with platinum-based $\mathrm{CHT}$, a modest improvement in overall survival was noted (11.3 months v. 10.1 months) over CHT alone. ${ }^{[89]}$ However, with other combination regimens, cetuximab has failed to demonstrate significant improvement in survival. ${ }^{[90]}$

\section{Anti-angiogenic agents}

Bevacizumab was the first targeted agent to demonstrate survival advantage in patients with advanced-stage NSCLC and is now routinely used in the first-line setting for patients with metastatic non-squamous NSCLC. The ECOG4599 ${ }^{[91]}$ trial tested 6 cycles of carboplatin-paclitaxel with or without bevacizumab given as monotherapy for non-progressive patients. The overall survival was superior for patients treated with bevacizumab (10.3 months v. 12.3 months, $p=0.003)$. The progression-free survival duration was also improved with bevacizumab (6.2 v. 4.5 months, $p<0.001)$. Treatment was tolerated well overall, with $<5 \%$ incidence of major bleeding events. Another trial (cisplatin and gemcitabine with either bevacizumab or placebo) noted similar efficacy, though a survival benefit was not evident. ${ }^{[92]}$ The AVAiL study also noted no increase in incidence of bleeding when bevacizumab-based regimens were given to patients on full dose anti-coagulation therapy. The safety and efficacy of bevacizumab have also been documented when used in combination with other commonly used platinum-based doublets for the treatment of advanced NSCLC. ${ }^{[93,94]}$ Despite promising phase II data, the combination of bevacizumab with erlotinib failed to improve survival in a randomised study conducted for second-line therapy of advanced-stage NSCLC. ${ }^{[95,96]}$ The same combination used as maintenance therapy also failed to improve survival compared with bevacizumab alone. ${ }^{[97]}$

Other vascular endothelial growth factor receptor inhibitors A number of novel multi-kinase inhibitors, which also target the vascular endothelial growth factor (VEGF) receptor, have all been tested for the treatment of advanced NSCLC. When given in combination with CHT, sorafenib failed to show an improvement in survival ${ }^{[98]}$ and in patients with squamous cell histology, the placebo group fared better. When combined with erlotinib in the second-line recurrent NSCLC, sorafenib demonstrated a modest improvement in efficacy in unselected patients when compared with erlotinib alone (PFS, 1.9 v. 3.1 months and OS 6.0 v. 8.1 months).$^{[99]}$ Vandetanib has also been studied in the front-line treatment of advanced NSCLC, where the combination of carboplatin and paclitaxel with vandetanib was associated with a modest improvement in median PFS over that of the same CHT given without vandetanib. ${ }^{[100]}$ In the second-line setting, docetaxel was given alone or in combination with vandetanib, ${ }^{[101]}$ with a modest and significant improvement in median PFS, though overall survival was not improved. In another study, vandetanib was added to pemetrexed for second-line therapy without significance. ${ }^{[102]}$ Vandetanib was also compared directly with erlotinib in a phase III study for advanced NSCLC and was noted to have comparable efficacy. ${ }^{[103]}$ Taken together, these results suggest a possible role of various VEGF receptor inhibitors.

\section{SCLC}

Small-cell lung cancer (SCLC) is a highly aggressive carcinoma and represents approximately $15-20 \%$ of all lung cancer cases. ${ }^{[104]}$ It is an entity of lung cancer that is biologically and clinically different from non-small-cell lung cancer. The World Health Organization (WHO) classification of a lung tumour, revised in $2004^{[105]}$ remains the cornerstone for lung cancer nomenclature. More than 4 decades ago, the Veterans Administration Lung Group had proposed dividing all SCLC into the two-stage system: limited disease (LD) and extensive disease (ED). ${ }^{[106]}$ The majority of clinicians and investigators still use it nowadays. The vast majority of patients (approximately two-thirds) fall into the ED SCLC, while LD SCLC occurs in approximately one-third of all SCLC. LD SCLC is defined as disease confined to the hemithorax of origin along with the involved regional lymph nodes (hilar and mediastinal), with or without ipsilateral supraclavicular lymph nodes. It can also be considered as a disease that can be incorporated within a single, tolerable TRT treatment field and may include patients with contralateral mediastinal or hilar lymph nodes. What has created confusion, and still does, is the term 'tolerable TRT treatment field'. It was not always easy to denote and compare it between clinicians, 
especially radiation oncologists. The most recent staging classification of SCLC ${ }^{[107]}$ represents an important refinement in overall approach in SCLC, while stratification by stage I - III also was recommended in clinical trials of LD SCLC.

\section{Limited disease}

Although surgery has occasionally been practised in this disease, it never became the standard treatment option owing to lack of data support. In addition, SCLC is known as a radio- and chemosensitive tumour and both CHT and TRT were used alone in LD SCLC in the past. However, results of two meta-analyses that appeared more than 2 decades ago ${ }^{[108,109]}$ summarised the data from prospective randomised trials showing small but significant improvement in 2-year and 3-year survival, averaging $5-7 \%$ and an improvement in local control rates with combined TRT-CHT. Importantly, the widespread use of cisplatin/etoposide and its low toxicity when combined with TRT made more effective use of concurrent TRT and platinum-based $\mathrm{CHT}$, which is nowadays considered as the standard treatment in LD SCLC. In addition, almost 15 years ago meta-analysis ${ }^{[110]}$ established the necessity to incorporate prophylactic cranial irradiation (PCI) as a mandatory part of the combined treatment.

Owing to its pronounced chemosensitivity, there are many CHT agents that achieve response rates of $\geq 30 \%$ in SCLC. They include cisplatin, carboplatin, etoposide, cyclophosphamide, doxorubicin, methotrexate and vincristine. ${ }^{[111]}$ In a phase III study, the cisplatin/ etoposide appeared superior to cyclophosphamide, epirubicin and vincristine in a randomised study. The 5 -year survival rates were $5 \%$ and $2 \%$ in the two treatment arms, respectively $(p=0.0004)$. In subgroup analysis done for 214 patients with LD SCLC, this benefit was even more pronounced (5-year survival, $10 \%$ v. $3 \%$; $p=0.0001$ ), while for patients having ED SCLC this benefit remained unreported. ${ }^{[112]}$ The use of cisplatin/etoposide in this disease has been additionally supported by a systematic review using 36 randomised trials that have tested single agents, either cisplatin or etoposide, or both (doublet) against regimens not containing these agents. The significant improvement with use of these drugs in comparison with CHT with neither was demonstrated. ${ }^{[113]}$ Furthermore, a meta-analysis of 19 trials that investigated the effects of CHT with or without cisplatin in more than 400 patients showed that patients receiving cisplatin had a survival advantage of $4.4 \%$ at 1 year. ${ }^{[14]}$ In addition, there are long-known facts about the favourable toxicity profile of cisplatin/etoposide regimen ${ }^{[108]}$ in combination with TRT.

Some studies advocated treatment of patients for the duration of their life. Only one study demonstrated a survival advantage for LD SCLC, ${ }^{[115]}$ while numerous studies showed either no advantage at all ${ }^{[16-122]}$ or even showing detrimental effects of continuous CHT. ${ }^{[123]}$ Additionally, some studies investigated the optimal number of induction CHT courses. Here, no survival benefit was seen for 8 cycles of cyclophosphamide/ etoposide/vincristine compared with 4 cycles, when there was an option of a second-line CHT. ${ }^{[124]}$ This was indirectly confirmed as early as 1996 by preliminary results of an Intergroup 0096 study that produced convincing results with only 4 cycles of cisplatin/ etoposide and TRT. ${ }^{[125]}$ Approaches to intensify the dose of CHT by giving higher doses including doxorubicin or alkylating-based CHT in the 1970s and 1980s, ${ }^{[126-128]}$ cisplatin-based in the 1990s, ${ }^{[129]}$ granulocyte colony-stimulating factor support, ${ }^{[130]}$ by decreasing the interval between the cycles of $\mathrm{CHT}^{[131,132]}$ or even using bone marrow support $^{[133]}$ all showed promising results but always and unequivocally accompanied with such high toxicity that prevented it becoming a standard treatment approach. Investigation of the place and the role of the third-generation drugs (e.g. Topotecan, Paclitaxel) showed they had no impact on survival. ${ }^{[134-136]}$ As a summary, there was no firm basis to recommend either dose intensification or the integration of new drugs into actual regimens owing to the risk of severe toxicity and the lack of clearly demonstrated improvement in overall survival. This is especially so when one considers the lack of data for CHT combined with TRT.

Timing of combined TRT and CHT, and total dose and fractionation used, attracted most of the attention of researchers. When timing of combined RT and CHT is considered it is usually defined as either concurrent, sequential or alternating. While some of the initial studies showed promising results for alternating RT and CHT, this type of combined approach is mostly abandoned today. The main question with the remaining two modes of administration is simply whether any portion of TRT and CHT overlap and, if this is the case, when overlapping occurs. Early concurrent thoracic TRT and CHT studies used non-platinum regimens or alternated it with cisplatin/ etoposide, while more recent ones were exclusively platinum-based regimens. Some studies ${ }^{[137-139]}$ suggested that TRT delayed until the fourth cycle of $\mathrm{CHT}^{[137]}$ or until day $120^{[138]}$ may be superior to initial TRT or suggested no difference when compared with early TRT and $\mathrm{CHT} \cdot{ }^{[139]}$ A likely explanation lies in marked reduction of CHT dose in trials ${ }^{[137,139]}$ when TRT was applied early. More recent studies using cisplatin/etoposide ${ }^{[140,141]}$ or cisplatin/etoposide alternating with cyclophosphamide/doxorubicin/vincristine ${ }^{[142]}$ showed clear superiority for early administration of TRT (concurrently given during the first or the second cycle of CHT). Early concurrent TRT and cisplatin/etoposide chemotherapy was capable of achieving 5-year survival of $>20 \%$, while late TRT usually obtained only about $10 \%$. Therefore, it became a common practice worldwide to offer TRT with curative doses as early as possible (cycle one or two of CHT). Recently, several meta-analyses and systematic reviews addressed this issue. However, while Huncharek and McGarry ${ }^{[143]}$ observed significantly superior survival for early TRT and CHT, Fried et al. ${ }^{[144]}$ observed a significantly higher 2-year survival in the early group with a suggestion of a similar trend at 3 and 5 years, Pijls-Johannesma et al. ${ }^{[145]}$ did not find any advantage for early TRT and CHT. These analyses ${ }^{[143-145]}$ brought somewhat conflicting results that were largely resolved by Jeremic, ${ }^{[146]}$ who performed 'meta-analysis of the metaanalyses', identifying common findings in existing analyses. Overall, prevailing evidence is that nowadays, using a 'standard' approach consisting of hyperfractionated TRT and four courses of CHT based on cisplatin-etoposide, early administration seems favourable and should be practised as the standard approach. Reports showing that prolonged (e.g. 4 - 6 cycles) sequential administration of CHT followed by radical TRT is an inferior treatment approach when compared with early and concurrent TRT-CHT are unfortunately still occurring nowadays. ${ }^{[147,148]}$

Regarding TRT dose and fractionation, total doses used for LD SCLC were usually about $50 \mathrm{~Gy}$, given daily, but have ranged from as low as $30 \mathrm{~Gy}$ to as high as $70 \mathrm{~Gy}$. In addition, many recent studies have used some form of hyperfractionation (b.i.d.). In the 
Intergroup study, ${ }^{[149]} 45$ Gy given in 30 fractions in 3 weeks (1.5 Gy b.i.d. fractionation) was compared with the same dose given once daily, both with concurrent cisplatin-etoposide CHT. While survival was significantly better in the b.i.d. arm (5-year, 26\% v. 19\%), this was however achieved with a somewhat higher incidence of acute toxicity. Beside hyperfractionation and conventional fractionation, hypofractionated RT regimens were also used, thought to cause more damage to SCLC cells. ${ }^{[142,150]}$ Currently, two major clinical trials investigating this issue are recruiting patients. In a CONVERT trial, EORTC is evaluating 66 Gy using standard fractionation with the b.i.d. fractionation as used in the Intergroup study (45 Gy in 30 fractions in 15 treatment days in 3 weeks). ${ }^{[149]}$ Similarly, joint CALGB 30610/RTOG 0538 is directly comparing the same control Intergroup regimen with two experimental arms, either conventional (QD) or concomitant boost regimen (CB). The better of the two experimental arms $(\mathrm{CB})$ is then being directly compared with hyperfractionated regimen. Mature data from these trials should hopefully give better perspective about the fractionation issue. Other regimens of b.i.d. irradiation (e.g. $54 \mathrm{~Gy}$ in 36 fractions in 18 treatment days in 3.5 weeks) have been successfully implemented in practice concurrently with low-dose CHT. ${ }^{[140]}$

\section{Extensive disease}

For decades, clinicians and investigators considered platinumetoposide $\mathrm{CHT}$ as the standard treatment option for patients with ED SCLC. As an exclusive treatment, it can offer the median survival time of 9 - 12 months and 5-year survivals of $1-3 \%{ }^{[151-153]}$ While up to $90 \%$ of patients eventually experience objective response following initial courses of CHT, ED SCLC remains a disease with very poor prognosis. This is because most patients unfortunately relapse, leading to outcomes virtually unchanged since platinum-etoposide was introduced several decades ago. It is therefore not hard to see this disease as one of the most frustrating challenges in thoracic oncology. To combat poor prognosis in patients with this disease when treated with CHT alone, various approaches aiming intensification of the treatment have been attempted. Unfortunately, maintenance CHT after 4 - 6 cycles of initial CHT with or without adding the thirdgeneration CHT drug ${ }^{[134,154,155]}$ and higher doses of chemotherapy ${ }^{[133,156]}$ did not prove to be beneficial in this setting. Other approaches such as adding the third CHT agent or using targeted agents did not result in any improvement.

In contrast stand findings of Slotman et al.. ${ }^{[157]}$ who published the results of a trial that changed the practice in ED SCLC by showing that PCI offers significant brain metastasis-free survival, relapse-free survival and overall survival in patients after achieving any response after induction CHT. Similarly to the place and role of PCI in LD SCLC, it is now accepted worldwide as the standard treatment option in responding patients with ED SCLC.

The case for curative TRT in ED SCLC is still an unsolved issue and is under active investigation. Although patients treated with CHT alone in ED SCLC frequently experience chest relapses, even in case of previous CR, TRT had not been systematically investigated in this setting. Also, one must take into account the systemic character of ED SCLC. It may obscure possible effects of TRT on survival (established on a local level), especially in adequately chosen subgroups of patients suitable for 'curative' role of TRT. Simply said, patients with ED SCLC may have systemic progression so fast that any possible effect on local control, and subsequently survival, may not be observed due to the short lifespan of these patients. The role of TRT in possible improvement in local (intrathoracic) tumour control and its subsequent impact, if any, on overall survival in favourable patient populations, was evaluated in a prospective randomised trial by Jeremic et al. ${ }^{[153]}$ After 3 cycles of cisplatin/etoposide regimen, complete patient reevaluation and restaging was performed and patients achieving CR (at local and distant levels) and those achieving partial response (PR) within the thorax accompanied with the CR elsewhere were then randomised to receive either a) TRT and concurrent lowdose daily CHT, followed by PCI and then by additional 2 cycles of CHT (group I) or b) 4 additional cycles of cisplatin-etoposide and PCI (group II). Patients in group I achieved results that were significantly better than those in group I: the median survival time was 17 v. 11 months ( $p=0.041$ ), and 5-year survival rates were $9.1 \%$ and $3.7 \%$ for groups I and II, respectively. Local recurrence-free survival was also better in group I than in group II, with median time to local recurrence of 30 and 22 months, respectively, and 5 -year local recurrence-free survival of $20 \%$ and $8.1 \%$, respectively $(p=0.062)$.

The study by Jeremic et al. ${ }^{[153]}$ was the very first prospective randomised study that evaluated curative TRT in ED SCLC. It showed that TRT may have an important place and may have a substantial role in overall treatment of patients with ED SCLC. Emerging reports worldwide confirm this observation. In a Canadian trial of Yee et al. ${ }^{[158]}$ the median time to disease progression was 8.4 months and the median overall survival time was 13.7 months, while in the study of Zhu et al., ${ }^{[159]}$ for TRT-treated group MST was 17.2 months, and 2 - and 5 -year survival was $36 \%$ and $10.1 \%$, respectively ( $p=0.0001$ ). Studies by Zhu et al ${ }^{[159]}$ and Yee et al..$^{[158]}$ should not only be seen as confirmatory data of the study of Jeremic et al. ${ }^{[153]}$ but also as confirmatory of existing institutional practices among thoracic oncologists involved in the treatment of ED SCLC since the study of Jeremic et al. ${ }^{[153]}$ This was recently brought to the evidence by the study of Ou et al. ${ }^{[159]}$ who retrospectively analysed the data from the Cancer Surveillance programmes of Orange, San Diego and Imperial counties in Southern California that indicated the use of TRT in ED SCLC in $35.1 \%$ of patients. The 1-year, 2-year, and median overall survival were $27.8 \%, 9.3 \%$ and 8 months and were significantly better than corresponding figures in patients who did not receive TRT (16.2\%, $3.8 \%$ and 4 months, respectively; $p<0.0001$ ). Two large ongoing studies (RTOG in the US and CREST in Holland) will add additional insight into the issue of place and role of TRT in ED SCLC.

\section{Conclusion}

Lung cancer has represented an active field of clinical research for many years. Treatment approaches have greatly improved over time, but unfortunately dismal treatment outcomes persist. It is expected that novel surgical and radiation oncology technologies as well as new drugs may help improve outcomes in patients with lung cancer. This should preferably be achieved using clinical trials as a vehicle to provide a high level of evidence, enabling its fast implementation in clinical practice worldwide. 


\section{References}

1. Jemal A, Center MM, DeSantis C, Ward EM. Global patterns of cancer incidence and mortality rates and trends. Cancer Epidemiol Biomarkers Prev 2010;19:1893-1907. [http://dx.doi.org/10.1158/1055-9965.EPI-10-0437]

2. Jemal A, Siegal R, Xu J, Ward E. Cancer Statistics,2010. CA Cancer J Clin 2010 July (epub). 2010;60(5):277-300. [http://dx.doi.org/10.3322/caac.20073]

3. Goldstraw P, Crowley J, Chansky K, Giroux DJ, Groome PA. The IASLC Lung Cancer Staging Project: Proposals for the revision of the TNM stage groupings in the forthcoming (seventh) edition of the TNM classification of malignant tumours. J Thorac Oncol 2007;2:706-714. [http://dx.doi.org/10.1097/JTO.0b013e31812f3cla]

4. Arriagada R, Dunant A, Pignon JP, et al. Long-term results of the international adjuvant lung cancer trial evaluating adjuvant cisplatin-based chemotherapy in resected lung cancer. J Clin Oncol 2010;28:35-42. [http://dx.doi.org/10.1200/ JCO.2009.23.2272]

5. Winton T, Livingston R, Johnson D, et al. Vinorelbine plus cisplatin vs. observation in resected non-small-cell lung cancer. N Engl J Med 2005;352:2589-9257. [http:// dx.doi.org/10.1056/NEJMoa043623]

6. Strauss GM, Herndon JE 2nd, Maddaus MA, et al. Adjuvant paclitaxel plus carboplatin compared with observation in stage IB non-small-cell lung cancer: CALGB 9633 with the Cancer and Leukemia Group B, Radiation Therapy Oncology Group, and North Central Cancer Treatment Group Study Groups. J Clin Oncol 2008;26:5043-5051. [http://dx.doi.org/10.1200/JCO.2008.16.4855]

7. Pignon JP, Tribodet H, Scagliotti GV, et al. Lung adjuvant cisplatin evaluation: a pooled analysis by the LACE Collaborative Group. J Clin Oncol 2008;26:3552-3559. [http://dx.doi.org/10.1200/JCO.2007.13.9030]

8. Pisters KM, Vallieres E, Crowley JJ, et al. Surgery with or without preoperative paclitaxel and carboplatin in early-stage non-small-cell lung cancer: Southwest Oncology Group Trial S9900, an intergroup, randomized, phase III trial. J Clin Oncol 2010;28:1843-1849.[http://dx.doi.org/10.1200/JCO.2009.26.1685]

9. Scagliotti G, Vansteenkiste J, Spaggiari L, et al. A phase III randomized study of surgery alone or surgery plus preoperative gemcitabine-cisplatin in early stage nonsmall cell lung cancer: Follow-up data of Ch.E.S.T. J Clin Oncol 2008;26(15s):399s.

10. Felip E, Rosell R, Maestre JA, et al. Preoperative chemotherapy plus surgery versus surgery plus adjuvant chemotherapy versus surgery alone in early-stage non-smallcell lung cancer. J Clin Oncol 2010;28:3138-3145. [http://dx.doi.org/10.1200/ JCO.2009.27.6204]

11. Goss G LI, Tsao MS, O'Callaghan CJ, et al. A phase II randomized, double-blind, placebo-controlled trial of the epidermal growth factor receptor inhibitor gefitinib in completely resected stage IB-IIIA non-small cell lung cancer (NSCLC): NCIC CTG BR.19. J Clin Oncol 2010;28(15s).

12. Jones DR, Stiles BM, Denlinger CE, et al. Pulmonary segmentectomy: Results and complications. Ann Thorac Surg 2003;76:343. [http://dx.doi.org/10.1016/S00034975(03)00437-5]

13. Schuchert MJ, Pettiford BL, Keeley S, et al. Anatomic segmentectomy in the treatment of stage I non-small cell lung cancer. Ann Thorac Surg 2007;84:926-932. [http://dx.doi.org/10.1016/j.athoracsur.2007.05.007]

14. Okada M, Nishio W, Sakamoto T, et al. Effect of tumor size on prognosis in patients with non-small cell lung cancer: The role of segmentectomy as a type of lesser resection. J Thorac Cardiovasc Surg 2005;129:87-93. [http://dx.doi.org/10.1016/j. jtcvs.2004.04.030]

15. Sugarbaker DJ. Lung cancer. 6: The case for limited surgical resection in non-small cell lung cancer. Thorax 2003;58:639-641. [http://dx.doi.org/10.1136/thorax.58.7.639]

16. Jeremic B, Classen J, Bamberg M: Radiation therapy alone in technically operable, medically inoperable early stage (I/II) non-small-cell lung cancer. Int J Radiat Oncol Biol Phys 2002;54:119-130. [http://dx.doi.org/10.1016/S0360-3016(02)02917-6]

17. Jeremic B, Milicic B, Acimovic L, Milisavljevic S. Concurrent hyperfractionated radiotherapy and low-dose daily carboplatin/paclitaxel in patients with early stage (I/II) non-small cell lung cancer (NSCLC). Long-term results of a phase II study. J Clin Oncol 2005;23:6873-6880. [http://dx.doi.org/10.1200/JCO.2005.22.319]

18. Nyman J, Johansson KA, Hulten U. Stereotactic hypofractionated radiotherapy for stage I non-small cell lung cancer - mature results for medically inoperable patients. Lung Cancer 2006;51:97-103. [http://dx.doi.org/10.1016/j.lungcan.2005.08.011]

19. Timmerman R, Paulus R, Galvin J, et al. Stereotactic body radiation therapy for inoperable early stage lung cancer. JAMA 2010;303:1070-1076. [http://dx.doi. org/10.1001/jama.2010.261]

20. Yendamuri S, Komaki RR, Correa AM, et al. Comparison of limited surgery and three-dimensional conformal radiation in high-risk patients with stage I non-small cell lung cancer. J Thorac Oncol 2007;2:1022-1028. [http://dx.doi.org/10.1097/ JTO.0b013e318158d4cb]

21. Grills IS, Mangona VS, Welsh R, et al. Outcomes after stereotactic lung radiotherapy or wedge resection for stage I non-small-cell lung cancer. J Clin Oncol 2010;28:928935. [http://dx.doi.org/10.1200/JCO.2009.25.0928]
22. Saunders M, Dische S, Barrett A, Harvey A, Griffiths G, Palmar M. Continuous hyperfractionated accelerated radiotherapy (CHART) versus conventional radiotherapy in non-small cell lung cancer: mature data from the randomisedmulticentre trial. Radiother Oncol 1999;52:137-148. [http://dx.doi. org/10.1016/S0167-8140(99)00087-0]

23. Dillman RO, Seagren SL, Propert KJ, et al. A randomized trial of induction chemotherapy plus high-dose radiation versus radiation alone in stage III nonsmall-cell lung cancer. N Engl J Med 1990;323:940-945. [http://dx.doi.org/10.1056/ NEJM199010043231403]

24. Sause WT, Scott C, Taylor S, et al: Radiation Therapy Oncology Group 88-08 and Eastern Cooperative Oncology Group 4588: Preliminary results of a phase III trial in regionally advanced, unresectable non-small cell lung cancer. J Natl Cancer Inst 1995;87:198-205. [http://dx.doi.org/10.1093/jnci/87.3.198]

25. Le Chevalier T, Arriagada R, Tarayre M, et al. Significant effect of adjuvant chemotherapy on survival in locally advanced non-small cell lung carcinoma (letter). J Natl Cancer Inst 1992;84:58. [http://dx.doi.org/10.1093/jnci/84.1.58]

26. Schaake-Koning C, van den Bogaert W, Dalesio O, et al. Effects of concomitant cisplatin and radiotherapy on inoperable non-small cell lung cancer. N Engl J Med 1992;326:524-530. [http://dx.doi.org/10.1056/NEJM199202203260805]

27. Jeremic B, Shibamoto Y, Acimovic L, Djuric L. Randomized trial of hyperfractionated radiation therapy with or without concurrent chemotherapy for stage III non-smallcell lung cancer. J Clin Oncol 1995;13:452-458.

28. Jeremic B, Shibamoto Y, Acimovic LJ, Milisavljevic S. Hyperfractionated radiation therapy with or without concurrent low-dose daily carboplatin/etoposide for stage III non-small-cell lung cancer: A randomized study. J Clin Oncol 1996;14:10651070 .

29. O’Rourke N, Roqué I Figuls M, Farré Bernadó N, Macbeth F. Concurrent chemoradiotherapy in non-small cell lung cancer. Cochrane Database Syst Rev 2010;6:CD002140.

30. Liang HY, Zhou H, Li XL, Yin ZH, Guan P, Zhou BS. Chemo-radiotherapy for advanced non-small cell lung cancer: Concurrent or sequential? It's no longer the question: A systematic review. Int J Cancer 2010;127:718-728. [http://dx.doi. org/10.1002/ijc.25087]

31. Aupérin A, le Péchoux C, Rolland E, et al. Meta-analysis of concomitant versus sequential radiochemotherapy in locally advanced non-small-cell lung cancer. J Clin Oncol 2010;28:2181-2190. [http://dx.doi.org/10.1200/JCO.2009.26.2543]

32. Shepherd FA, Johnston MR, Payne D, et al. Randomized study of chemotherapy and surgery versus radiotherapy for stage IIIA non-small-cell lung cancer: A National Cancer Institute of Canada Clinical Trials Group Study. Br J Cancer 1998;78:683-685 [http://dx.doi.org/10.1038/bjc.1998.560]

33. Johnstone DW, Byhardt RW, Ettinger D, Scott CB. Phase III study comparing chemotherapy and radiotherapy with preoperative chemotherapy and surgical resection in patients with non-small-cell lung cancer with spread to mediastinal lymph nodes (N2); final report of RTOG 89-01. Radiation Therapy Oncology Group. Int J Radiat Oncol Biol Phys 2002;54:365-369. [http://dx.doi.org/10.1016/S0360-3016(02)02943-7]

34. Van Meerbeeck JP, Kramer GW, van Schil PE, et al. Randomized controlled trial of resection versus radiotherapy after induction chemotherapy in stage IIIA-N2 non-small-cell lung cancer. J Natl Cancer Inst 2007;99:442-450. [http://dx.doi. org/10.1093/jnci/djk093]

35. Albain KS, Swann RS, Rusch VW, et al. Radiotherapy plus chemotherapy with or without surgical resection for stage III non-small-cell lung cancer: A phase III randomised controlled trial. Lancet 2009;374:379-386. [http://dx.doi.org/10.1016/ S0140-6736(09)60737-6]

36. Medical Research Council Lung Cancer Working Party. Inoperable non-small-cell lung cancer (NSCLC): A Medical Research Council randomised trial of palliative radiotherapy with two fractions or ten fractions. Br J Cancer 1991;63:265-270. [http://dx.doi.org/10.1038/bjc.1991.62]

37. Medical Research Council Lung Cancer Working Party. A Medical Research Council (MRC) randomised trial of palliative radiotherapy with two fractions or a single fraction in patients with inoperable non-small cell lung cancer (NSCLC) and poor performance status. Br J Cancer 1992;65:931-941. [http://dx.doi.org/10.1038/bjc.1992.196]

38. Medical Research Council Lung Cancer Working Party. Randomised trial of palliative 2 -fraction versus more intensive 13 -fraction radiotherapy for patients with inoperable non-small cell lung cancer and good performance status. Clin Oncol 1996;8:167-175. [http://dx.doi.org/10.1016/S0936-6555(96)80041-0]

39. Rees GJG, Devrell CE, Barley VL, et al. Palliative radiotherapy for lung cancer: Two versus five fractions. Clin Oncol (R Coll Radiol) 1997;9:90-95. [http://dx.doi org/10.1016/S0936-6555(05)80446-7]

40. Bezjak A, Dixon P, Brundage M, et al. Randomized phase III trial of single versus fractionated thoracic radiation in the palliation of patients with lung cancer (NCIC CTG SC.15) Int J Radiat Oncol Biol Phys 2002;54:719-728. [http://dx.doi. org/10.1016/S0360-3016(02)02989-9] 
41. Sundstrøm S, Bremnes R, Aasebø U, et al. Hypofractionated palliative radiotherapy (17 Gy per two fractions) in advanced non-small-cell lung carcinoma is comparable to standard fractionation for symptom control and survival: A national phase III trial. J Clin Oncol 2004;22:801-810. [http://dx.doi.org/10.1200/JCO.2004.06.123]

42. Erridge SC, Gaze MN, Price A, et al. Symptom control and quality of life in people with lung cancer: A randomised trial of two palliative radiotherapy fractionation schedules. Clin Oncol 2005;17:61-67. [http://dx.doi.org/10.1016/j.clon.2004.09.008]

43. Kramer G, Wanders SL, Noordijk EM, et al. Results of the Dutch National Study of the palliative effect of irradiation using two different treatment schemes for nonsmall-cell lung cancer. J Clin Oncol 2005;13:2962-2970. [http://dx.doi.org/10.1200/ JCO.2005.01.685]

44. Senkus-Konefka E, Dziadziuszko R, Bednaruk-Mlynski E, et al. A prospective randomised study to compare two palliative radiotherapy schedules for non-smallcell cancer (NSCLC). Br J Cancer 2005;92:1038-1045. [http://dx.doi.org/10.1038/ sj.bjc.6602477]

45. Simpson JR, Francis ME, Perez-Tamayo R, et al. Palliative radiotherapy for inoperable carcinoma of the lung: Final report of a RTOG multi-institutional trial. Int J Radiat Oncol Biol Phys 1985;11:751-758. [http://dx.doi.org/10.1016/0360-3016(85)90307-4]

46. Teo P, Tai TH, Choy D, et al. A randomized study on palliative radiation therapy for inoperable non-small cell carcinoma of the lung. Int J Radiat Oncol Biol Phys 1987;14:867-871. [http://dx.doi.org/10.1016/0360-3016(88)90007-7]

47. Abratt RP, Shepherd LJ, Mameena Salton DG. Palliative radiation for stage 3 nonsmall cell lung cancer. A prospective study of two moderately high dose regimens. Lung Cancer 1995;13:137-143. [http://dx.doi.org/10.1016/0169-5002(95)00487-4]

48. Reinfuss M, Glinski B, Kowalska T, et al. Radiothérapie du cancer bronchique non á petites cellules de stade III inoperable asymptomatique. Résultats définitifs d’un essai prospectif randomisé (240 patients). Cancer Radiother 1999;3:475-479. [http:// dx.doi.org/10.1016/S1278-3218(00)88254-2]

49. Nestle U, Nieder $\mathrm{C}$, Walter $\mathrm{K}$, et al. A palliative accelerated irradiation regimen for advanced non-small-cell lung cancer vs conventionally fractionated $60 \mathrm{~Gy}$ : Results of a randomized equivalence study. Int J Radiat Oncol Biol Phys 2000;48:195-203. [http://dx.doi.org/10.1016/S0360-3016(00)00607-6]

50. Sundstrøm S, Bremnes R, Brunsvig P, et al. Palliative thoracic radiotherapy in locally advanced non-small cell lung cancer: Can quality-of-life assessments help in selection of patients for short- or long-course radiotherapy? J Thorac Oncol 2006;1:816-824. [http://dx.doi.org/10.1097/01243894-200610000-00010]

51. MacManus MP, Matthews JP, Wada M, et al. Unexpected long-term survival after low-dose palliative radiotherapy for nonsmall cell lung cancer. Cancer 2005;116:1110-1116

52. NSCLC Meta-analysis Collaborative Group. Chemotherapy in addition to supportive care improves survival in advanced non-small-cell lung cancer: A systematic review and meta-analysis of individual patient data from 16 randomized controlled trials. J Clin Oncol 2008;26:4617-4625. [http://dx.doi.org/10.1200/JCO.2008.17.7162]

53. Falk S, Girling DJ, White RJ, et al. Immediate versus delayed palliative thoracic radiotherapy in patients with unresectable locally advanced non-small cell lung cancer and minimal thoracic symptoms: Randomised controlled trial. BMJ 2002;325:465-468. [http://dx.doi.org/10.1136/bmj.325.7362.465]

54. Sundstrøm S, Bremnes R, Brunsvig P, et al. Immediate or delayed radiotherapy in advanced non-small cell lung cancer (NSCLC)? Data from a prospective randomised study. Radiother Oncol 2005;75:141-148. [http://dx.doi.org/10.1016/j. radonc.2005.03.028]

55. Bunn PA Jr. Chemotherapy for advanced non-small-cell lung cancer: Who, what, when, why? J Clin Oncol 2002; 20(18 Suppl):23S-33S.

56. Rapp E, Pater JL, Willan A, et al. Chemotherapy can prolong survival in patients with advanced non-small-cell lung cancer - report of a Canadian multicenter randomized trial. J Clin Oncol 1988;6:633-641.

57. Schiller JH, Harrington D, Belani CP, et al. Comparison of four chemotherapy regimens for advanced non-small-cell lung cancer. N Engl J Med 2002;346:92-98. [http://dx.doi.org/10.1056/NEJMoa011954]

58. Kelly K, Crowley J, Bunn PA Jr, et al. Randomized phase III trial of paclitaxel plus carboplatin versus vinorelbine plus cisplatin in the treatment of patients with advanced non-small-cell lung cancer: A Southwest Oncology Group trial. J Clin Oncol 2000;19:3210-3218.

59. Wozniak AJ, Crowley JJ, Balcerzak SP, et al. Randomized trial comparing cisplatin with cisplatin plus vinorelbine in the treatment of advanced non-small-cell lung cancer: A Southwest Oncology Group study. J Clin Oncol 1998;16:2459-2465.

60. Sandler AB, Nemunaitis J, Denham C, et al. Phase III trial of gemcitabine plus cisplatin versus cisplatin alone in patients with locally advanced or metastatic nonsmall-cell lung cancer. J Clin Oncol 2000;18:122-130.

61. Lilenbaum RC, Herndon JE 2nd, List MA, et al. Single-agent versus combination chemotherapy in advanced non-small-cell lung cancer: the cancer and leukemia group B (study 9730). J Clin Oncol 2005;23:190-196. [http://dx.doi.org/10.1200/ JCO.2005.07.172]
62. Ohe Y, Ohashi Y, Kubota K, et al. Randomized phase III study of cisplatin plus irinotecan versus carboplatin plus paclitaxel, cisplatin plus gemcitabine, and cisplatin plus vinorelbine for advanced non-small-cell lung cancer: Four-Arm Cooperative Study in Japan. Ann Oncol 2007;18:317-323. [http://dx.doi.org/10.1093/annonc/mdl377]

63. Fossella F, Pereira JR, von Pawel J, et al. Randomized, multinational, phase III study of docetaxel plus platinum combinations versus vinorelbine plus cisplatin for advanced non-small-cell lung cancer: The TAX 326 study group. J Clin Oncol 2003;21:30163024. [http://dx.doi.org/10.1200/JCO.2003.12.046]

64. Scagliotti GV, Parikh P, von Pawel J, et al. Phase III study comparing cisplatin plus gemcitabine with cisplatin plus pemetrexed in chemotherapy-naive patients with advanced-stage non-small-cell lung cancer. J Clin Oncol 2008;26:3543-3551. [http:// dx.doi.org/10.1200/JCO.2007.15.0375]

65. Belani CP, Lee JS, Socinski MA, et al. Randomized phase III trial comparing cisplatinetoposide to carboplatin-paclitaxel in advanced or metastatic non-small cell lung cancer. Ann Oncol 2005;16:1069-1075. [http://dx.doi.org/10.1093/annonc/mdi216]

66. Alberola V, Camps C, Provencio M, et al. Cisplatin plus gemcitabine versus a cisplatin-based triplet versus nonplatinum sequential doublets in advanced nonsmall-cell lung cancer: A Spanish Lung Cancer Group phase III randomized trial. J Clin Oncol 2003;21:3207-3213. [http://dx.doi.org/10.1200/JCO.2003.12.038]

67. Ramalingam S, Belani CP. State-of-the-art chemotherapy for advanced non-small cell lung cancer. Semin Oncol 2004;31(1 Suppl 1):68-74. [http://dx.doi.org/10.1053/j. seminoncol.2003.12.017]

68. Eismann U, Oberschmidt O, Ehnert M, et al. Pemetrexed: mRNA expression of the target genes TS, GARFT and DHFR correlates with the in vitro chemosensitivity of human solid tumors. Int J Clin Pharmacol Ther 2005;43:567-569. [http://dx.doi. org/10.5414/CPP43567]

69. Righi L, Papotti MG, Ceppi P, et al. Thymidylate synthase but not excision repair cross-complementation group 1 tumor expression predicts outcome in patients with malignant pleural mesothelioma treated with pemetrexed-based chemotherapy. J Clin Oncol 2010;28:1534-1539. [http://dx.doi.org/10.1200/JCO.2009.25.9275]

70. Monica V, Scagliotti GV, Ceppi P, et al. Differential thymidylate synthase expression in different variants of large-cell carcinoma of the lung. Clin Cancer Res 2009;15:75477552. [http://dx.doi.org/10.1158/1078-0432.CCR-09-1641]

71. Socinski MA, Schell MJ, Peterman A, et al. Phase III trial comparing a defined duration of therapy versus continuous therapy followed by second-line therapy in advanced-stage IIIB/IV non-small-cell lung cancer. J Clin Oncol 2002;20:1335-1343. [http://dx.doi.org/10.1200/JCO.20.5.1335]

72. Smith IE, O'Brien ME, Talbot DC, et al. Duration of chemotherapy in advanced nonsmall-cell lung cancer: A randomized trial of three versus six courses of mitomycin, vinblastine, and cisplatin. J Clin Oncol 2001;19:1336-1343.

73. Ciuleanu T, Brodowicz T, Zielinski C, et al. Maintenance pemetrexed plus best supportive care versus placebo plus best supportive care for non-small-cell lung cancer: a randomised, double-blind, phase 3 study. Lancet. 2009;374:1432-1440. [http://dx.doi.org/10.1016/S0140-6736(09)61497-5]

74. Cappuzzo F, Ciuleanu T, Stelmakh L, et al. Erlotinib as maintenance treatment in advanced non-small-cell lung cancer: A multicentre, randomised, placebocontrolled phase 3 study. Lancet Oncol 2010;11:521-529. [http://dx.doi.org/10.1016/ S1470-2045(10)70112-1]

75. Soon YY SM, Askie LM, Boyer MJ. Duration of chemotherapy for advanced nonsmall-cell lung cancer: A systematic review and meta-analysis of randomized trials. J Clin Oncol 2009;27:3277-3283. [http://dx.doi.org/10.1200/JCO.2008.19.4522]

76. Belani CP, Ghazal H, Ramalingam SS, et al. Phase III study of maintenance gemcitabine (G) and best supportive care (BSC) versus BSC, following standard combinatin therapy with gemcitabine-carboplatin (G-Cb) for patients with advanced non-small cell lung cancer (NSCLC). J Clin Oncol 2010;28(15s).

77. Perez-Soler R, Chachoua A, Hammond LA, et al. Determinants of tumor response and survival with erlotinib in patients with non-small-cell lung cancer. J Clin Oncol 2004;22:3238-3247. [http://dx.doi.org/10.1200/JCO.2004.11.057]

78. Kris MG, Natale RB, Herbst RS, et al. Efficacy of gefitinib, an inhibitor of the epidermal growth factor receptor tyrosine kinase, in symptomatic patients with non-small cell lung cancer: A randomized trial. JAMA 2003;290:2149-2158. [http:// dx.doi.org/10.1001/jama.290.16.2149]

79. Fukuoka M, Yano S, Giaccone G, et al. Multi-institutional randomized phase II trial of gefitinib for previously treated patients with advanced non-small-cell lung cancer (The IDEAL 1 Trial) [corrected]. J Clin Oncol 2003;21:2237-2246. [http://dx.doi. org/10.1200/JCO.2003.10.038]

80. Shepherd FA, Rodrigues Pereira J, et al. Erlotinib in previously treated non-smallcell lung cancer. N Engl J Med 2005;353:123-132. [http://dx.doi.org/10.1056/ NEJMoa050753]

81. Thatcher N, Chang A, Parikh P, et al. Gefitinib plus best supportive care in previously treated patients with refractory advanced non-small-cell lung cancer: Results from a randomised, placebo-controlled, multicentre study (Iressa Survival Evaluation in Lung Cancer). Lancet 2005;366:1527-1537. [http://dx.doi.org/10.1016/S0140-6736(05)67625-8] 
82. Paez JG, Janne PA, Lee JC, et al. EGFR mutations in lung cancer: Correlation with clinical response to gefitinib therapy. Science 2004;304:1497-1500. [http://dx.doi. org/10.1126/science.1099314]

83. Mok TS, Wu YL, Thongprasert S, et al. Gefitinib or carboplatin-paclitaxel in pulmonary adenocarcinoma. N Engl J Med 2009;361:947-957. [http://dx.doi. org/10.1056/NEJMoa0810699]

84. Han JY, Park K, Kim SW, et al. First-SIGNAL: First-line single-agent iressa versus gemcitabine and cisplatin trial in never-smokers with adenocarcinoma of the lung. J Clin Oncol 2012;30:1122-1128. [http://dx.doi.org/10.1200/JCO.2011.36.8456]

85. Herbst RS, Giaccone G, Schiller JH, et al. Gefitinib in combination with paclitaxel and carboplatin in advanced non-small-cell lung cancer: A phase III trial - INTACT 2. J Clin Oncol 2004;22:785-794. [http://dx.doi.org/10.1200/JCO.2004.07.215]

86. Giaccone G, Herbst RS, Manegold C, et al. Gefitinib in combination with gemcitabine and cisplatin in advanced non-small-cell lung cancer: A phase III trial - INTACT 1. J Clin Oncol 2004;22:777-784. [http://dx.doi.org/10.1200/JCO.2004.08.001]

87. Jänne $\mathrm{PA}$, Wang $\mathrm{X}$, Jones $\mathrm{D}$, et al. Randomized phase II trial of erlotinib alone or with carboplatin and paclitaxel in patients who were never or light former smokers with advanced lung adenocarcinoma: CALGB 30406 trial. J Clin Oncol 2012;30:20632069. [http://dx.doi.org/10.1200/JCO.2011.40.1315]

88. Hanna N, Lilenbaum R, Ansari R, et al. Phase II trial of cetuximab in patients with previously treated non-small-cell lung cancer. J Clin Oncol 2006;24:5253-5258. [http://dx.doi.org/10.1200/JCO.2006.08.2263]

89. Pirker R, Pereira JR, Szczesna A, et al. Cetuximab plus chemotherapy in patients with advanced non-small-cell lung cancer (FLEX): An open-label randomised phase III trial. Lancet 2009;373:1525-1531. [http://dx.doi.org/10.1016/S0140-6736(09)605699]

90. Lynch TJ, Patel T, Dreisbach L, et al. Cetuximab and first-line taxane/carboplatin chemotherapy in advanced non-small-cell lung cancer: Results of the randomized multicenter phase III trial BMS099. J Clin Oncol 2010;28:911-917. [http://dx.doi. org/10.1200/JCO.2009.21.9618]

91. Sandler A, Gray R, Perry MC, et al. Paclitaxel-carboplatin alone or with bevacizumab for non-small-cell lung cancer. N Engl J Med 2006;355:2542-2550. [http://dx.doi. org/10.1056/NEJMoa061884]

92. Reck M, von Pawel J, Zatloukal P, et al. Phase III trial of cisplatin plus gemcitabine with either placebo or bevacizumab as first-line therapy for nonsquamous nonsmall-cell lung cancer: AVAil. J Clin Oncol 2009;27:1227-1234. [http://dx.doi. org/10.1200/JCO.2007.14.5466]

93. Patel JD, Hensing TA, Rademaker A, et al. Phase II study of pemetrexed and carboplatin plus bevacizumab with maintenance pemetrexed and bevacizumab as first-line therapy for nonsquamous non-small-cell lung cancer. J Clin Oncol 2009;27:3284-3289. [http://dx.doi.org/10.1200/JCO.2008.20.8181]

94. Kris MPK, Rusch V, Zhao B, Schwartz L, Guo P, Tan Y. Phase II trial of induction and adjuvant bevacizumab with cisplatin and docetaxel in patients with locally advanced non-small cell lung cancer. J Thorac Oncol 2009;4:S372.

95. Herbst RS, O'Neill VJ, Fehrenbacher L, et al. Phase II study of efficacy and safety of bevacizumab in combination with chemotherapy or erlotinib compared with chemotherapy alone for treatment of recurrent or refractory non smallcell lung cancer. J Clin Oncol 2007;25:4743-4750. [http://dx.doi.org/10.1200/ JCO.2007.12.3026]

96. Herbst RS, Ansari R, Bustin F, et al. Efficacy of bevacizumab plus erlotinib versus erlotinib alone in advanced non-small-cell lung cancer after failure of standard firstline chemotherapy (BeTa): A double-blind, placebo-controlled, phase 3 trial. Lancet 2011;377:1846-1854. [http://dx.doi.org/10.1016/S0140-6736(11)60545-X]

97. Miller V, Soh C, Kabbinavar F. A randomized, double-blind, placebo-controlled, phase IIIb trial (ATLAS) comaring bevacizumab (B) therapy with or without erlotinib (E) after completion of chemotherpay with B for first-line treatment of locally advanced, recurrent, or metastatic non-small cell lung cancer (NSCLC). J Clin Oncol 2009;27(15S).

98. Scagliotti G, Novello S, von Pawel J, et al. Phase III study of carboplatin and paclitaxel alone or with sorafenib in advanced non-small-cell lung cancer. J Clin Oncol 2010;28:1835-1842. [http://dx.doi.org/10.1200/JCO.2009.26.1321]

99. Spigel DR, Burris HA 3rd, Greco FA, et al. Randomized, double-blind, placebocontrolled, phase II trial of sorafenib and erlotinib or erlotinib alone in previously treated advanced non-small-cell lung cancer. J Clin Oncol 2011;29: 2582-2589. [http://dx.doi.org/10.1200/JCO.2010.30.7678]

100. Heymach JV, Paz-Ares L, de Braud F, et al. Randomized phase II study of vandetanib alone or with paclitaxel and carboplatin as first-line treatment for advanced nonsmall-cell lung cancer. J Clin Oncol 2008;26:5407-5415. [http://dx.doi.org/10.1200/ JCO.2008.17.3138]

101. Herbst RS, Sun Y, Eberhardt WE, et al. Vandetanib plus docetaxel versus docetaxel as second-line treatment for patients with advanced non-small-cell lung cancer (ZODIAC): A double-blind, randomised, phase 3 trial. Lancet Oncol 2010;11:619626. [http://dx.doi.org/10.1016/S1470-2045(10)70132-7]
102. De Boer RH, Arrieta Ó, Yang CH, et al. Vandetanib plus pemetrexed for the secondline treatment of advanced non-small-cell lung cancer: A randomized, doubleblind phase III trial. J Clin Oncol 2011;29:1067-1074. [http://dx.doi.org/10.1200/ JCO.2010.29.5717]

103. Natale RB, Thongprasert S, Greco FA, et al. Phase III trial of vandetanib compared with erlotinib in patients with previously treated advanced non-small-cell lung cancer. J Clin Oncol 2011;29:1059-1066. [http://dx.doi.org/10.1200/JCO.2010.28.5981]

104. Greenlee RT, Murray T, Bolden S, Wingo PA. Cancer statistics 2000. CA Cancer J Clin 2000;50:7-33. [http://dx.doi.org/10.3322/canjclin.50.1.7]

105. Travis WD, Brambilla E, Muller-Hermlink HK, Harris CC. World Health Organization Classification of Tumours. Pathology and Genetics of Tumours of the Lung, Pleura, Thymus and Heart. Lyon: IARC Press, 2004.

106. Green RA, Humphrey E, Close H, Patno ME. Alkylating agents in bronchogenic carcinoma. Am J Med 1969;6:516-525. [http://dx.doi.org/10.1016/00029343(69)90071-0]

107. Shepherd FA, Crowley J, van Houtte P, et al The International Association for the Study of Lung Cancer Lung Cancer Staging Project: Proposals regarding the clinical staging of small-cell lung cancer in the forthcoming (seventh) edition of the tumor, node, metastasis classification for lung cancer. J Thorac Oncol 2007;2:1067-1077. [http://dx.doi.org/10.1097/JTO.0b013e31815bdc0d]

108. Pignon JP, Arriagada R, Ihde DC, et al. A meta-analysis of thoracic radiotherapy for small-cell lung cancer. N Engl J Med 1992;327:1618-1627. [http://dx.doi.org/10.1056/ NEJM199212033272302]

109. Warde P, Payne D. Does thoracic radiation improve survival and local control in limited-stage small cell carcinoma of the lung? J Clin Oncol 1992;10:890-895.

110. Auperin A, Arriagada R, Pignon JP, et al. Prophylactic cranial irradiation for patients with small-cell lung cancer in complete remission. Prophylactic Cranial Irradiation Overview Collaborative Group. N Engl J Med 1999;341:476-484. [http://dx.doi. org/10.1056/NEJM199908123410703]

111. Sandler AB. Chemotherapy for small cell lung cancer. Semin Oncol 2003;30:9-25. [http://dx.doi.org/10.1053/sonc.2003.50012]

112. Sundstrøm S, Bremnes RM, Kaasa S, et al. Cisplatin and etoposide regimen is superior to cyclophosphamide, epirubicin, and vincristine regimen in small-cell lung cancer: Results from a randomized phase III trial with 5 years' follow-up. J Clin Oncol 2002;20:4665-4672. [http://dx.doi.org/10.1200/JCO.2002.12.111]

113. Mascaux C, Paesmans M, Berghmans T, et al. A systematic review of the role of etoposide and cisplatin in the chemotherapy of small cell lung cancer with methodology assessment and meta-analysis. Lung Cancer 2000;30:23-36. [http:// dx.doi.org/10.1016/S0169-5002(00)00127-6]

114. Pujol JL, Carestia L, Daurès JP. Is there a case for cisplatin in the treatment of smallcell lung cancer? A meta-analysis of randomized trials of a cisplatin-containing regimen versus a regimen without this alkylating agent. Br J Cancer 2000;83:8-15.

115. Maurer LH, Tulloh M, Weiss R, et al. A randomized combined modality trial on small cell carcinoma of the lung. Cancer 1980;45:30-39. [http://dx.doi.org/10.1002/10970142(19800101)45:1<30::AID-CNCR2820450107>3.0.CO;2-6]

116. Woods RL, Levi JA. Chemotherapy for small cell lung cancer (SCLC): A randomised study of maintenance therapy with cyclophosphamide, adriamycin and vincristine (CAV) after remission induction with cis-platinum (CIS-DDP), VP 16-213 and radiotherapy. Proc Am Soc Clin Oncol 1984;3:214.

117. Cullen M, Morgan D, Gregory W, et al. Maintenance chemotherapy for anaplastic small cell carcinoma of the bronchus: A randomised, controlled trial. Cancer Chemother Pharmacol 1986;17:157-160. [http://dx.doi.org/10.1007/BF00306746]

118. Bleehen NM, Fayers PM, Girling DJ, Stephens RJ. Controlled trial of twelve versus six courses of chemotherapy in the treatment of small-cell lung cancer. Br J Cancer 1989;59:584-590. [http://dx.doi.org/10.1038/bjc.1989.118]

119. Lebeau B, Chastang CL, Allard P, Migueres J, Boita F, Fichet D. Six vs. twelve cycles for complete responders to chemotherapy in small cell lung cancer: Definitive results of a randomised clinical trial. Eur Respir J 1992;5:286-290.

120. Giaccone G, Dalesio O, McVie GJ, et al. Maintenance chemotherapy in small-cell lung cancer: Long-term results of a randomized trial. J Clin Oncol 1993;11:1230-1240.

121. Beith JM, Clarke SJ, Woods RL, Bell DR, Levi JA. Long-term follow-up of a randomised trial of combined chemoradiotherapy induction treatment, with and without maintenance chemotherapy in patients with small cell carcinoma of the lung. Eur J Cancer 1996;32A:438-443. [http://dx.doi.org/10.1016/0959-8049(95)00608-7]

122. Sculier JP, Paesmans M, Bureau G, et al. Randomized trial comparing induction chemotherapy versus induction chemotherapy followed by maintenance chemotherapy in small-cell lung cancer. J Clin Oncol 1996;14:2337-2344.

123. Byrne MJ, van Hazel G, Trotter J, et al. Maintenance chemotherapy in limited small cell lung cancer: A randomised controlled clinical trial. Br J Cancer 1989;59:584-590. [http://dx.doi.org/10.1038/bjc.1989.118]

124. Spiro SG, Souhami RL, Geddes DM, et al. Duration of chemotherapy in small cell lung cancer: A Cancer Research Campaign trial. Br J Cancer 1989;59:578-583. [http://dx.doi.org/10.1038/bjc.1989.117] 
125. Johnson DH, Kim K, Sause W. Cisplatin (p) \& etoposide (e) + thoracic radiotherapy (TRT) administered once or twice daily (bid) in limited stage (LS) small cell lung cancer (SCLC): Final report of intergroup trial 0096. Proc Am Soc Clin Oncol 1996;15:374.

126. Cohen MH, Broder LE, Fossieck BE, Ihde DC, Minna JD. Intensive chemotherapy of small cell bronchogenic carcinoma. Cancer Treat Rep 1977;61:349-354.

127. Mehta C, Vogl SE, Farber S. High-dose cyclophosphamide (C) in the induction (IND) chemotherapy (CT) of small cell lung cancer (SCLC) - Minor improvements in rate of remission and survival. Proc Am Assoc Cancer Res 1982;23:165.

128. Figueredo AT, Hryniuk WM, Strautmanis I, Frank G, Rendell S. Cotrimoxazole prophylaxis during high-dose chemotherapy of small-cell lung cancer. J Clin Oncol 1985;3:54-64.

129. Arriagada R, le Chevalier T, Pignon JP, et al. Initial chemotherapeutic doses and survival in patients with limited small-cell lung cancer. N Engl J Med 1993;25:18481852. [http://dx.doi.org/10.1056/NEJM199312163292504]

130. Ardizzoni A, Tjan-Heijnen VCG, Postmus PE, et al. Standard versus intensified chemotherapy with granulocyte colony-stimulating factor support in small-cell lung cancer: A prospective European Organization for research and treatment of cancer Lung Cancer Group phase III trial - 08923. J Clin Oncol 2002;20:3947-3955. [http:// dx.doi.org/10.1200/JCO.2002.02.069]

131. Steward WP, von Pawel J, Gatzemaier U, et al. Effects of granulocyte colony-stimulating factor and dose-intensification of V-ICE chemotherapy in small-cell lung cancer: A prospective randomised study of 300 patients. J Clin Oncol 1998;16:642-650.

132. Thatcher N, Girling DJ, Howood P, Sambrook RJ, Qian W, Stephens RJ. Improving survival without reducing quality of life in small-cell lung cancer patients by increasing the dose-intensity of chemotherapy with granulocyte colony-stimulating factor support: Results of a British Medical Research Council multicenter randomised trial. J Clin Oncol 2000;18:395-404.

133. Leyvraz S, Pampallona S, Martinelli G, et al. A threefold dose intensity treatment with ifosfamide, carboplatin, and etoposide for patients with small cell lung cancer: A randomized trial. J Natl Cancer Inst 2008;100:533-541. [http://dx.doi.org/10.1093/ jnci/djn088]

134. Schiller JH, Adak S, Cella D, DeVore RF 3rd, Johnson DH. Topotecan versus observation after cisplatin plus etoposide in extensive-stage small-cell lung cancer: E7593 - a phase III trial of the Eastern Cooperative Oncology Group. J Clin Oncol 2001;19:2114-2122.

135. Mavroudis D, Papadakis E, Veslemes M, et al. A multicenter randomized clinical trial comparing paclitaxel-cisplatin-etoposide versus cisplatin-etoposide as firstline treatment in patients with small-cell lung cancer. Ann Oncol 2001;12:463-470. [http://dx.doi.org/10.1023/A:1011131303391]

136. Niell HB, Herndon JE, Miller AA. Randomized phase III intergroup trial (CALGB 9732) of etoposide and cisplatin with or without paclitaxel and G-CSF in patients with extensive stage small cell lung cancer. Proc Am Soc Clin Oncol 2002;21:293a.

137. Perry MC, Eaton WL, Propert KJ, et al. Chemotherapy with or without radiation therapy in limited small-cell carcinoma of the lung. N Engl J Med 1987;316:912-918. [http://dx.doi.org/10.1056/NEJM198704093161504]

138. Schultz HP, Nielsen OS, Sell A. Timing of chest radiation with respect to combination chemotherapy in small cell lung cancer, limited disease(Abstract). Lung Cancer 1988;4:153.

139. Work E, Nielsen O, Bentzen S, Fode K, Palshof T. Randomized study of initial versus late chest irradiation combined with chemotherapy in limited-stage small cell lung cancer. J Clin Oncol 1997;15:3030-3037.

140. Jeremic B, Shibamoto Y, Acimovic L, Milisavljevic S. Initial versus delayed accelerated hyperfractionated radiation therapy and concurrent chemotherapy in limited small cell lung cancer. J Clin Oncol 1997;15:893-900.

141. Takada M, Fukuoka M, Kawahara M, et al. Phase III study of concurrent versus sequential thoracic radiotherapy in combination with cisplatin and etoposide for limited-stage small-cell lung cancer: Results of the Japan Clinical Oncology Group study 9104. J Clin Oncol 2002;20:3054-3060. [http://dx.doi.org/10.1200/ JCO.2002.12.071]
142. Murray N, Coy, Pater J, et al. Importance of timing for thoracic irradiation in the combined modality treatment of limited stage small cell lung cancer. J ClinOncol1993; 11: 336-344.

143. Huncharek M, McGarry R. A meta-analysis of the timing of chest irradiation in the combined modality treatment of limited-stage small cell lung cancer. Oncologist 2004;9:665-762. [http://dx.doi.org/10.1634/theoncologist.9-6-665]

144. Fried DB, Morris DE, Poole C, et al. Systematic review evaluating the timing of thoracic radiation therapy in combined modality therapy for limited-stage smallcell lung cancer. J Clin Oncol 2004;22:4837-4845. [http://dx.doi.org/10.1200/ JCO.2004.01.178]

145. Pijls-Johannesma MC, de Ruysscher D, Lambin P, Rutten I, Vansteenkiste JF. Early versus late chest radiotherapy for limited stage small cell lung cancer. Cochrane Database Syst Rev 2005;1:CD004700.

146. Jeremic B. Timing of concurrent radiotherapy and chemotherapy in limited-disease small-cell lung cancer: "Meta-analysis of meta-analyses". Int J Radiat Oncol Biol Phys 2006;64:981-982. [http://dx.doi.org/10.1016/j.ijrobp.2005.10.034]

147. El Sharouni SY, Kal HB, Barten-Van Rijbroek A, Struikmans H, Battermann JJ, Schramel FM. Concurrent versus sequential chemotherapy and radiotherapy in limited disease small cell lung cancer: A retrospective comparative study. Anticancer Res 2009;29:5219-5224.

148. Yilmaz U, Anar C, Korkmaz E, Yapicioglu S, Karadogan I, Ozkök S. Carboplatin and etoposide followed by once-daily thoracic radiotherapy in limited disease small-cell lung cancer: Unsatisfactory results. Tumori 2010;96:234-240.

149. Turrisi AT, Kim K, Blum R, et al. Twice-daily compared with once-daily thoracic radiotherapy in limited small-cell lung cancer treated concurrently with cisplatin and etoposide. N Engl J Med 1999;340:264-271. [http://dx.doi.org/10.1056/ NEJM199901283400403]

150. Spiro SG, James LE, Rudd RM, et al. Early compared with late radiotherapy in combined modality treatment for limited disease small-cell lung cancer: A London Lung Cancer Group multicenter randomized clinical trial and meta-analysis. J Clin Oncol 2006;24:3823-3830. [http://dx.doi.org/10.1200/JCO.2005.05.3181]

151. Bunn PA Jr, Cohen MH, Ihde DC, Fossieck BE Jr, Matthews MJ, Minna JD. Advances in small cell bronchogenic carcinoma: a commentary. Cancer Treat Rep 1977;61:333342.

152. Beck LK, Kane MA, Bunn PA Jr. Innovative and future approaches to small cell lung cancer treatment. Semin Oncol 1988;15:300-314.

153. Jeremic B, Shibamoto Y, Nikolic N, et al The role of radiation therapy in the combined modality treatment of patients with extensive disease small-cell lung cancer (ED SCLC): A randomized study. J Clin Oncol 1999;17:2092-2099.

154. Splinter TAW. Chemotherapy of small cell lung cancer (SCLC): duration of treatment. Lung Cancer 1989;5:186-196. [http://dx.doi.org/10.1016/0169-5002(89)90167-0]

155. Bunn PA Jr. Clinical experience with carboplatin (paraplatin) in lung cancer. SeminOncol 1992;19(suppl 2):1-11.

156. Ihde DC, Mulshine JL, Kramer BS, et al. Prospective randomized comparison of high-dose and standard-dose etoposide and cisplatin chemotherapy in patients with extensive-stage small cell lung cancer. J Clin Oncol 1994;12:2022-2034.

157. Slotman B, Faivre-Finn C, Kramer G, et al. Prophylactic cranial irradiation in extensive small-cell lung cancer. N Engl J Med 2007;357:664-672. [http://dx.doi. org/10.1056/NEJMoa071780]

158. Yee D, Butts C, Reiman A, et al. Clinical trial of post-chemotherapy consolidation thoracic radiotherapy for extensive-stage small cell lung cancer. Radiother Oncol 2012;102:234-238. [http://dx.doi.org/10.1016/j.radonc.2011.08.042]

159. Zhu H, Zhou Z, Wang Y, et al. Thoracic radiation therapy improves the overall survival of patients with extensive-stage small cell lung cancer with distant metastasis. Cancer 2011;117:5423-5431. [http://dx.doi.org/10.1002/cncr.26206]

160. Ou S-HI, Ziogas A, Zell JA. Prognostic factors for survival in extensive stage small cell lung cancer (ED-SCLC). The importance of smoking history, socioeconomic and marital statuses, and ethnicity. J Thorac Oncol 2009;4:37-43. [http://dx.doi. org/10.1097/JTO.0b013e31819140fb] 
Poor inhaler technique is a common problem resulting in inadequate drug delivery and decreased asthma control.'

\section{clever. simple. intuitive.}

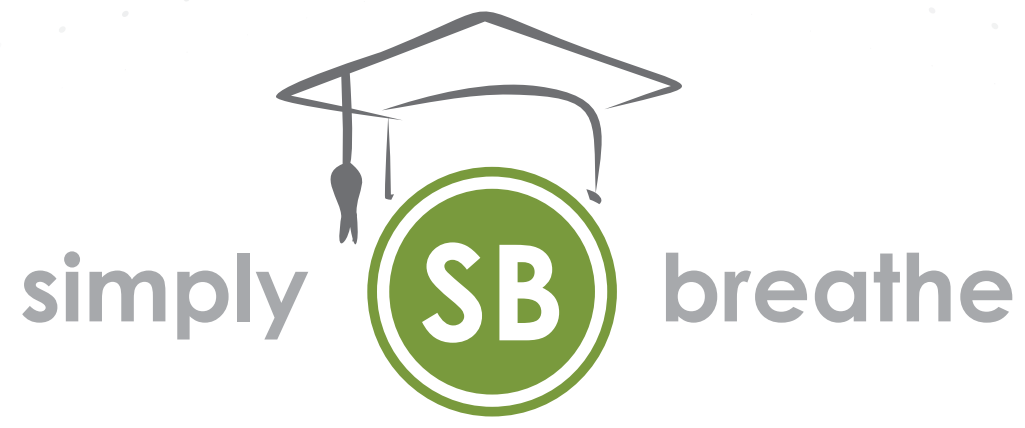

COMING SOON

PATENTED BY 